\title{
RESEARCH INTO KINETIC REGULARITIES OF THE REACTION OF OXIDATIVE DEHYDROGENATION OF METHYLCYCLOHEXANE OVER MODIFIED ZEOLITES
}

\author{
A.I. Karimov \\ M.F. Nagiyev Institute of Catalysis and Inorganic Chemistry, \\ National Academy of Sciences of Azerbaijan \\ H. Javid ave., 113, Baku AZ 1143, e-mail: kerimov.alibala@mail.ru
}

Received 09.03.2021

Accepted 05.05.2021

\begin{abstract}
Kinetic regularities of the oxidative dehydrogenation reaction of methylcyclohexane on the $\mathrm{CoCr}$ clinoptilolite catalyst were investigated. Absence of internal and external diffusion inhibition was established, the reaction proceeds in the kinetic area, in which all diffusion stages proceed much faster than all chemical stages that make up the mechanism of this reaction. The influence of partial pressures of reagents, the reaction temperature and the space velocity of the reaction mixture on the course of the reaction was studied and optimal conditions for obtaining the intentional reaction product determined.

Keywords: methylcyclohexane, methylcyclohexadiene, oxidative dehydrogenation, clinoptilolite, naphthenic hydrocarbons.
\end{abstract}

DOI: $10.32737 / 2221-8688-2021-1-41-46$

\section{Introduction}

The kinetic modeling of experimental data and the development of a model equation can be applied in the design of a chemical reactor. Knowledge of the reaction mechanism in describing what actually happens during a chemical reaction makes it possible to perform the safe extrapolation and optimization of reaction variables and thus assist in better development and design of a new catalyst and catalyst system [1].

The mechanism of formation of diene hydrocarbons in terms of heterogeneous oxidative dehydrogenation of naphthenic hydrocarbons has for long been a subject of discussion [2-5].

There are many schools of thought and disagreements in the literature regarding the kinetic mechanism of the oxidative dehydrogenation of naphthenic hydrocarbons to the corresponding diene hydrocarbons. Therefore, the detailed and rigorous kinetic analysis of extensive experimental datais necessitated.

The article depicts the outcomes of studying the kinetic regularities of the oxidative dehydrogenation of methyl-cyclohexane in order to clarify the possible mechanism of the reaction.

\section{Experimental part}

The results of the experimental investigation over selection of an active catalyst for the oxidative dehydrogenation of methyl cyclohexane showed that a metal zeolite catalyst synthesized on the basis of natural zeolite clinoptilolite by ion exchange and containing cations $\quad\left(\mathrm{Co}_{2}+-0.5 \% ; \mathrm{Cr}_{3}+-0.25 \%\right)$ exhibits the highest activity in reactions of oxidative dehydrogenation of methylcyclohexane to methylcyclohexadiene 1,3. On this basis, the kinetic regularities of the course of the reaction were studied with the participation of this catalyst [6]. 
Table 1. Influence of catalyst particle sizes and linear velocity of the initial reaction mixture in the course of the reaction at a molar ratio of $\mathrm{C}_{7} \mathrm{H}_{14}: \mathrm{O}_{2}: \mathrm{N}_{2}=1: 1: 5.3, \mathrm{~V}_{\mathrm{h}}=1.026 \mathrm{~h}^{-1}, \mathrm{~T}=3800{ }^{\circ} \mathrm{C}$

\begin{tabular}{|c|c|c|c|}
\hline$№$ & Catalyst particle size, $\mathrm{mm}$ & $\begin{array}{c}\text { Linear velocity of the } \\
\text { reaction mixture, } \mathrm{m} / \mathrm{h}\end{array}$ & $\begin{array}{c}\text { Methylcyclohexadiene-1,3 } \\
\text { yield, \% }\end{array}$ \\
\hline 1 & $0.23-0.40$ & 73.56 & 15.7 \\
\hline 2 & $0.23-0.40$ & 35.72 & 15.8 \\
\hline 3 & $0.23-0.40$ & 24.46 & 16.1 \\
\hline 4 & $0.23-0.40$ & 18.34 & 15.7 \\
\hline 5 & $0.40-0.63$ & 73.56 & 15.7 \\
\hline 6 & $0.40-0.63$ & 35.72 & 15.8 \\
\hline 7 & $0.40-0.63$ & 24.46 & 16.1 \\
\hline 8 & $0.40-0.63$ & 18.34 & 15.8 \\
\hline 9 & $0.63-1.25$ & 73.56 & 15.7 \\
\hline 10 & $0.63-1.25$ & 35.72 & 15.6 \\
\hline 11 & $0.63-1.25$ & 24.46 & 15.9 \\
\hline 12 & $0.63-1.25$ & 18.34 & 15.8 \\
\hline 13 & $1.25-1.75$ & 73.56 & 15.1 \\
\hline 14 & $1.25-1.75$ & 35.72 & 15.9 \\
\hline 15 & $1.25-1.75$ & 24.46 & 15.7 \\
\hline 16 & $1.25-1.75$ & 18.34 & 15.6 \\
\hline 17 & $1.75-2.00$ & 73.56 & 15.8 \\
\hline 18 & $1.75-2.00$ & 35.72 & 15.9 \\
\hline 19 & $1.75-2.00$ & 24.46 & \\
\hline 20 & $1.75-2.00$ & 18.34 & \\
\hline & & & \\
\hline
\end{tabular}

Preceding to studying the kinetic laws of the reaction, the region of occurrence was determined. For this purpose, a series of experiments was carried out with various sizes of catalyst grains: $0.25-0.40 \mathrm{~mm}, 0.40-0.63 \mathrm{~mm}$, $0.63-1.25 \mathrm{~mm}, 1.25-1.60 \mathrm{~mm}, 1.60-2.00 \mathrm{~mm}$ and various linear velocities of the initial reaction mixture. The linear velocity varied by changing the volume of the catalyst at equal volumetric velocities [Table 1]. As follows from data in Table 1, a change in the size and linear velocity of the initial reaction mixture does not have a significant effect on the main parameters of the process; therefore, there are no internal and external diffusion inhibitions, i.e. the reaction proceeds in the kinetic region, in which all diffusion stages proceed much faster than all the chemical stages constituting the mechanism of this reaction. Kinetic experiments were carried out on a flow-through laboratory setup in the temperature range $320-380{ }^{\circ} \mathrm{C}$, volumetric velocities 500-3000 h-1, partial pressures of reagents $\mathrm{P}_{\mathrm{C} 7 \mathrm{H} 14}=0.04-0.14$ atm; $\mathrm{P}_{\mathrm{O} 2}=0.07-0.25$ atm. The results of experimental studies of the kinetic laws in the process of oxidative conversion of methylcyclohexane are presented in Table 2-4. The reaction produces methylcyclohexene $\left(\mathrm{A}_{1}\right)$, methylcyclohexadiene $\left(A_{2}\right)$, toluene $\left(A_{3}\right)$, and carbon dioxide $\left(\mathrm{A}_{4}\right)$. As you can see from Table 2 , an increase in $\mathrm{P}_{\mathrm{O} 2}$ from 0.04 to 0.14 atm leads to an increase in the yield of methicyclohexadiene-1,3 which is explained as being due to an increase in the concentration of surface oxygen, and with a further increase in $\mathrm{P}_{\mathrm{O} 2}$ to $0.2 \mathrm{~atm}$. decreases slightly. In the entire studied range, the conversion of methylcyclohexane (X) is continuously increasing. 
Table 2. Influence of oxygen partial pressure on oxidative dehydrogenation of methylcyclohexane on CoCr-clinoptilolite catalyst $\mathrm{Vo}=2500 \mathrm{~h}^{-1} ; \mathrm{V}_{\mathrm{C} 7 \mathrm{H} 14}=0.69 \mathrm{l} / \mathrm{h} ;=0.02255 \mathrm{~mol} / \mathrm{h} ;=0.11 \mathrm{~atm}$; $\mathrm{G}_{\mathrm{cat}}=1.78 \mathrm{~g}$

\begin{tabular}{|c|c|c|c|c|c|c|c|c|c|c|c|}
\hline $\mathrm{T},{ }^{0} \mathrm{C}$ & $n_{C_{7} H_{14}}^{0}$ & $n_{O_{2}}^{0}$ & $n_{N_{2}}^{0}$ & $P_{\mathrm{C}_{6} \mathrm{H}_{11} \mathrm{CH}_{3}}$ & $P_{O_{2}}$ & $P_{N_{2}}$ & $\mathrm{X}, \%$ & $A_{1}$ & $\mathrm{~A}_{2}$ & $A_{3}$ & $\mathrm{~A}_{4}$ \\
\hline \multirow{4}{*}{320} & 0.02255 & 0.00858 & 0.16768 & 0.11 & 0.04 & 0.84 & 4.25 & 1.5 & 0.6 & 2.1 & 0.05 \\
\hline & 0.02255 & 0.01799 & 0.15828 & 0.11 & 0.09 & 0.79 & 9.2 & 1.9 & 2.8 & 4.2 & 0.3 \\
\hline & 0.02255 & 0.02822 & 0.14805 & 0.11 & 0.14 & 0.75 & 10.7 & 2.2 & 3.1 & 4.6 & 0.8 \\
\hline & 0.02255 & 0.03926 & 0.13701 & 0.11 & 0.20 & 0.69 & 13.9 & 2.0 & 2.9 & 6.8 & 2.2 \\
\hline \multirow{4}{*}{340} & 0.02255 & 0.00858 & 0.16768 & 0.11 & 0.04 & 0.84 & 11.4 & 3.2 & 2.6 & 3.8 & 1.8 \\
\hline & 0.02255 & 0.01799 & 0.15828 & 0.11 & 0.09 & 0.79 & 19.4 & 3.9 & 6.2 & 6.8 & 2.5 \\
\hline & 0.02255 & 0.02822 & 0.14805 & 0.11 & 0.14 & 0.75 & 21.2 & 4.4 & 6.5 & 7.0 & 3.3 \\
\hline & 0.02255 & 0.03926 & 0.13701 & 0.11 & 0.20 & 0.69 & 24.2 & 3.7 & 5.9 & 9.5 & 5.1 \\
\hline \multirow{4}{*}{360} & 0.02255 & 0.00858 & 0.16768 & 0.11 & 0.04 & 0.84 & 23.7 & 5.8 & 6.6 & 6.4 & 4.9 \\
\hline & 0.02255 & 0.01799 & 0.15828 & 0.11 & 0.09 & 0.79 & 31.1 & 6.2 & 10.5 & 8.6 & 5.8 \\
\hline & 0.02255 & 0.02822 & 0.14805 & 0.11 & 0.14 & 0.75 & 33.8 & 6.7 & 11.1 & 9.3 & 6.7 \\
\hline & 0.02255 & 0.03926 & 0.13701 & 0.11 & 0.20 & 0.69 & 38.3 & 6.4 & 10.7 & 12.3 & 8.9 \\
\hline \multirow{4}{*}{380} & 0.02255 & 0.00858 & 0.16768 & 0.11 & 0.04 & 0.84 & 36.3 & 6.9 & 10.5 & 10.1 & 8.8 \\
\hline & 0.02255 & 0.01799 & 0.15828 & 0.11 & 0.09 & 0.79 & 44.8 & 7.1 & 15.8 & 11.6 & 10.3 \\
\hline & 0.02255 & 0.02822 & 0.14805 & 0.11 & 0.14 & 0.75 & 46.6 & 7.2 & 15.7 & 12.2 & 11.5 \\
\hline & 0.02255 & 0.03926 & 0.13701 & 0.11 & 0.20 & 0.69 & 49.9 & 7.0 & 14.4 & 15.8 & 12.7 \\
\hline \multirow{4}{*}{400} & 0.02255 & 0.00858 & 0.16768 & 0.11 & 0.04 & 0.84 & 38.7 & 6.3 & 9.2 & 13.0 & 10.2 \\
\hline & 0.02255 & 0.01799 & 0.15828 & 0.11 & 0.09 & 0.79 & 47.2 & 6.5 & 13.5 & 14.9 & 12.3 \\
\hline & 0.02255 & 0.02822 & 0.14805 & 0.11 & 0.14 & 0.75 & 49.9 & 7.2 & 14.4 & 15.6 & 12.7 \\
\hline & 0.02255 & 0.03926 & 0.13701 & 0.11 & 0.20 & 0.69 & 55.1 & 6.5 & 14.0 & 18.8 & 15.8 \\
\hline
\end{tabular}

Table 3 shows that in the studied temperature range at a volumetric velocity of $2000 \mathrm{~h}^{-1}$, constant $\mathrm{P}_{\mathrm{O} 2}(0.14$ atm. $)$ And $\mathrm{P}_{\mathrm{C} 7 \mathrm{H} 14}$ variation from 0.06 to $0.25 \mathrm{~atm}$., the dependence of the yield of methylcyclohexadiene-1,3 has an extreme feature and passes through a maximum. The maximum output is achieved when $\mathrm{P}_{\mathrm{C} 6 \mathrm{H} 12}=$ 0.11 atm. Further increase in $\mathrm{P}_{\mathrm{C} 7 \mathrm{H} 14}$ to $0.25 \mathrm{~atm}$. leads to a decrease in the yield of methylcyclohexadiene-1,3 and conversion of methylcyclohexane. The decrease in the conversion of methylcyclohexane is explained as being due to the fact that at a given partial pressure of oxygen, the relatively high partial pressures of methylcyclohexane prevent the coordination of oxygen with active sites of the metal zeolite catalyst.

Table 3. Effect of the partial pressure of methylcyclohexane on the oxidative dehydrogenation of methylcyclohexane on the CoCr-clinoptilolite catalyst $\mathrm{Vo}=2000 \mathrm{~h}^{-1} ; \mathrm{V}_{\mathrm{O} 2}=0.69 \mathrm{l} / \mathrm{h} ;=0.02822$ $\mathrm{mol} /$ hour $=0.14 \mathrm{~atm} ; \mathrm{G}_{\mathrm{cat}}=1.78 \mathrm{~g}$

\begin{tabular}{|c|c|c|c|c|c|c|c|c|c|c|c|}
\hline $\begin{array}{c}\mathrm{T}, \\
\mathrm{C}\end{array}$ & $n_{C_{7} H_{14}}^{0}$ & $n_{O_{2}}^{0}$ & $n_{N_{2}}^{0}$ & $P_{C_{7} H_{14}}$ & $P_{O_{2}}$ & $P_{N_{2}}$ & $\mathrm{X}, \%$ & $\mathrm{~A}_{1}$ & $\mathrm{~A}_{2}$ & $\mathrm{~A}_{3}$ & $\mathrm{~A}_{4}$ \\
\hline \multirow{4}{*}{320} & 0.01143 & 0.02822 & 0.16196 & 0.06 & 0.14 & 0.80 & 11.4 & 0.8 & 1.9 & 7.5 & 1.2 \\
\cline { 2 - 13 } & 0.02255 & 0.02822 & 0.14805 & 0.11 & 0.14 & 0.75 & 10.7 & 2.2 & 3.1 & 4.6 & 0.8 \\
\cline { 2 - 13 } & 0.03382 & 0.02822 & 0.13395 & 0.17 & 0.14 & 0.68 & 9.9 & 3.4 & 2.9 & 3.1 & 0.5 \\
\cline { 2 - 12 } & 0.04509 & 0.02822 & 0.11983 & 0.25 & 0.14 & 0.61 & 8.5 & 4.1 & 2.0 & 2.2 & 0.2 \\
\hline \multirow{3}{*}{340} & 0.01143 & 0.02822 & 0.16196 & 0.06 & 0.14 & 0.80 & 22.6 & 3.6 & 5.2 & 9.3 & 4.5 \\
\cline { 2 - 11 } & 0.02255 & 0.02822 & 0.14805 & 0.11 & 0.14 & 0.75 & 21.2 & 4.4 & 6.5 & 7.0 & 3.3 \\
\cline { 2 - 11 } & 0.03382 & 0.02822 & 0.13395 & 0.17 & 0.14 & 0.68 & 18.4 & 5.2 & 6.0 & 5.4 & 1.8 \\
\hline
\end{tabular}




\begin{tabular}{|c|c|c|c|c|c|c|c|c|c|c|c|}
\hline & 0.04509 & 0.02822 & 0.11983 & 0.25 & 0.14 & 0.61 & 15.4 & 6.0 & 3.9 & 4.5 & 1.0 \\
\hline \multirow{4}{*}{360} & 0.01143 & 0.02822 & 0.16196 & 0.06 & 0.14 & 0.80 & 35.1 & 6.2 & 9.8 & 11.5 & 7.6 \\
\cline { 2 - 11 } & 0.02255 & 0.02822 & 0.14805 & 0.11 & 0.14 & 0.75 & 33.8 & 6.7 & 11.1 & 9.3 & 6.7 \\
\cline { 2 - 11 } & 0.03382 & 0.02822 & 0.13395 & 0.17 & 0.14 & 0.68 & 30.8 & 8.0 & 10.8 & 7.8 & 4.2 \\
\cline { 2 - 12 } & 0.04509 & 0.02822 & 0.11983 & 0.25 & 0.14 & 0.61 & 27.4 & 8.7 & 8.5 & 6.9 & 3.3 \\
\hline \multirow{3}{*}{380} & 0.01143 & 0.02822 & 0.16196 & 0.06 & 0.14 & 0.80 & 48.4 & 7.4 & 13.9 & 15.0 & $\begin{array}{c}13 . \\
1\end{array}$ \\
\cline { 2 - 12 } & 0.02255 & 0.02822 & 0.14805 & 0.11 & 0.14 & 0.75 & 46.6 & 7.2 & 15.7 & 12.2 & $\begin{array}{c}11 . \\
5\end{array}$ \\
\cline { 2 - 12 } & 0.03382 & 0.02822 & 0.13395 & 0.17 & 0.14 & 0.68 & 43.2 & 9.1 & 15.5 & 10.3 & 8.2 \\
\cline { 2 - 12 } & 0.04509 & 0.02822 & 0.11983 & 0.25 & 0.14 & 0.61 & 39.1 & 9.9 & 12.8 & 10.2 & 6.2 \\
\hline & 0.01143 & 0.02822 & 0.16196 & 0.06 & 0.14 & 0.80 & 51.1 & 6.9 & 11.0 & 19.1 & $\begin{array}{c}14 . \\
1\end{array}$ \\
\cline { 2 - 11 } & 0.02255 & 0.02822 & 0.14805 & 0.11 & 0.14 & 0.75 & 49.9 & 7.2 & 14.4 & 15.6 & $\begin{array}{c}12 . \\
7\end{array}$ \\
\cline { 2 - 11 } & 0.03382 & 0.02822 & 0.13395 & 0.17 & 0.14 & 0.68 & 47.1 & 8.5 & 14.2 & 14.2 & $\begin{array}{c}10 . \\
2\end{array}$ \\
\cline { 2 - 11 } & 0.04509 & 0.02822 & 0.11983 & 0.25 & 0.14 & 0.61 & 40.5 & 9.2 & 10.1 & 13.3 & 7.9 \\
\hline
\end{tabular}

It follows from results above that optimal partial pressures of the reagents at which the highest yield of methylcyclohexadiene-1,3 is achieved are: $\mathrm{P}_{\mathrm{C} 7 \mathrm{H} 14}=0.11$ atm. and $\mathrm{P}_{\mathrm{O} 2}=0.14$ atm. The effect of temperature and space velocity in the course of the reaction was studied at optimal $\mathrm{P}_{\mathrm{C} 7 \mathrm{H} 14}$ and $\mathrm{P}_{\mathrm{O} 2}$; the results of these studies are presented in Table 4. From Table 4 it follows that as temperature rises from $320^{\circ} \mathrm{C}$ to $400^{\circ} \mathrm{C}$, the yield of methylcyclohexadiene-1,3 grows continuously.

Table 4. Influence of temperature and space velocity on the process of oxidative dehydrogenation of cyclohexane on a $\mathrm{CoCr}$ - clinoptilolite catalyst at a molar ratio of $\mathrm{C}_{6} \mathrm{H}_{12}: \mathrm{O}_{2}: \mathrm{N}_{2}$ $=1.00: 1.00: 5.3 ; \mathrm{G}_{\text {cat }}=1.78 \mathrm{q} ; \mathrm{V}_{\text {cat }}=2 \mathrm{~cm}^{3}$

\begin{tabular}{|c|c|c|c|c|c|c|c|c|c|c|}
\hline № & $\mathrm{n}_{\mathrm{C}_{6} \mathrm{H}_{11} \mathrm{CH}_{3}}^{0}$ & $n_{\mathrm{O}_{2}}^{0}$ & $n_{N_{2}}^{0}$ & $\mathrm{~V}_{\mathrm{h},} \mathrm{h}^{-1}$ & $\mathrm{~T},{ }^{0} \mathrm{C}$ & $\mathrm{X}, \%$ & $\mathrm{~A}_{1}$ & $A_{2}$ & $\mathrm{~A}_{3}$ & $\mathrm{~A}_{4}$ \\
\hline 1 & \multirow{5}{*}{0.00902} & \multirow{5}{*}{0.01129} & \multirow{5}{*}{0.05922} & \multirow{5}{*}{1000} & 320 & 16.45 & 0.05 & 0.6 & 11.9 & 3.9 \\
\hline 2 & & & & & 340 & 26.59 & 0.09 & 1.9 & 16.8 & 7.8 \\
\hline 3 & & & & & 360 & 35.2 & 1.1 & 3.4 & 20.9 & 9.8 \\
\hline 4 & & & & & 380 & 47.2 & 1.5 & 5.0 & 23.8 & 16.9 \\
\hline 5 & & & & & 400 & 51.7 & 1.3 & 4.8 & 25.9 & 19.7 \\
\hline 6 & \multirow{5}{*}{0.01804} & \multirow{5}{*}{0.022576} & \multirow{5}{*}{0.14806} & \multirow{5}{*}{2000} & 320 & 12.9 & 0.9 & 1.5 & 8.7 & 1.8 \\
\hline 7 & & & & & 340 & 23.1 & 1.9 & 3.6 & 12.7 & 4.9 \\
\hline 8 & & & & & 360 & 34.9 & 3.7 & 5.7 & 17.2 & 8.3 \\
\hline 9 & & & & & 380 & 46.2 & 4.6 & 8.2 & 20.3 & 13.1 \\
\hline 10 & & & & & 400 & 50.8 & 4.2 & 7.8 & 23.5 & 15.3 \\
\hline 11 & \multirow{5}{*}{0.02255} & \multirow{5}{*}{0.028226} & \multirow{5}{*}{0.14806} & \multirow{5}{*}{2500} & 320 & 10.7 & 2.2 & 3.1 & 4.6 & 0.8 \\
\hline 12 & & & & & 340 & 21.2 & 4.4 & 6.5 & 7.0 & 3.3 \\
\hline 13 & & & & & 360 & 33.8 & 6.7 & 11.1 & 9.3 & 6.7 \\
\hline 14 & & & & & 380 & 46.6 & 7.2 & 15.7 & 12.2 & 11.5 \\
\hline 15 & & & & & 400 & 49.9 & 7.2 & 14.4 & 15.6 & 12.7 \\
\hline
\end{tabular}




\begin{tabular}{|c|c|c|c|c|c|c|c|c|c|c|}
\hline 16 & \multirow{5}{*}{0.02706} & \multirow{5}{*}{0.03386} & \multirow{5}{*}{0.77661} & \multirow{5}{*}{3000} & 320 & 10.3 & 5.2 & 3.2 & 1.6 & 0.3 \\
\hline 17 & & & & & 340 & 19.9 & 6.9 & 6.9 & 3.7 & 2.4 \\
\hline 18 & & & & & 360 & 31.7 & 10.1 & 11.3 & 6.1 & 4.2 \\
\hline 19 & & & & & 380 & 43.7 & 12.0 & 15.9 & 9.6 & 6.2 \\
\hline 20 & & & & & 400 & 47.1 & 11.2 & 14.3 & 12.8 & 8.8 \\
\hline
\end{tabular}

With an upsurge in the space velocity from $1000^{\text {to }} 3000^{\mathrm{h}-1}$, the conversion of methylcyclohexane decreases due to a decrease in the contact time (Fig. 1). A decrease in the

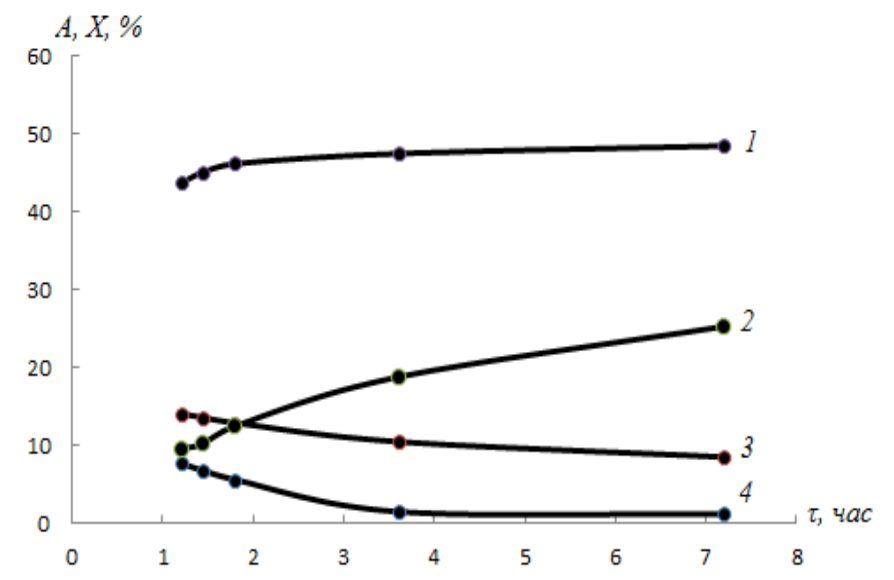

contact time prevents the preoxidative dehydrogenation of these products into toluene and deep oxidation to $\mathrm{CO}_{2}$.

Fig. 1. Dependences of the conversion (X) of methylcyclohexane (1) and the yields (A) of the reaction products of methylcyclohexene (2), methylcyclohexadiene (3), and toluene (4) on the conditional contact time at a molar ratio of $\mathrm{C}_{6} \mathrm{H}_{12}$ : $\mathrm{O}_{2}: \mathrm{N}_{2}=1: 1: 5.3$ and $\mathrm{T}=380^{\circ} \mathrm{C}$
If we assume that this reaction proceeds according to a sequential mechanism with the formation of toluene, respectively, then for the reaction of oxidative dehydrogenation of methylcyclohexane - methylcyclohexene and methylcyclohexadiene-1,3 these are intermediate products Fig. 1. It can be seen that the nature of curves of the dependences of the yields of intermediate and final products on the conditional contact time does not correspond to the sequential mechanism of the reaction. Thus, on the basis of the experimental data obtained, it can be concluded that on the surface of the catalysts there are different active centers consisting of their components, which are responsible for the formation of reaction products, which is consistent with [7].

\section{References}

1. Ezzo E. M., Mazhar H. S., Ali S. A., and Youssef N. A. Investigation of the mechanism of dehydrogenation of cycloalkanes over $\mathrm{Cu} / \mathrm{Al}_{2} \mathrm{O}_{3}$ catalyst. Chem. Papers, 1991, vol. 45 (5), pp. 625-641.

2. Yagodovsky V.D., Iehu Z.V., Isaeva N.Yu., Yagodovskaya T.V., Kifyak R.A., Belyaeva K.S. Dehydrogenation of cyclohexane on industrial platinum catalyst AP-64, subjected to plasma-chemical treatments. Russian Journal of Physical Chemistry. 2009, vol. 83 (5), pp. 847-851.

3. Pines H., Csicery S.M. Dehydrogenation, dehydrocyclization and isomerization of $\mathrm{C}_{5^{-}}$ $\mathrm{C}_{6}$ hydrocarbons over chromia-alumina catalysts. J. Amer. Chem. Soc. 1962, vol. 84 (2), pp. 292-299.

4. Bruce E. Koel, David A. Blank, Emily A. Carter. Thermochemistry of the selective dehydrogenation of cyclohexane to benzene on Pt surfaces. Journal of Molecular Catalysis A. 1998, vol. 131, pp. 39-53.

5. Rajesh B. Biniwale, Nobuko Kariya, Masaru Ichikawa. Dehydrogenation of cyclohexane over $\mathrm{Ni}$ based catalysts supported on activated carbon using spray-pulsed reactor and enhancement in activity by addition of a small amount of Pt. Catalysis Letters. 2005, vol.105, pp. 83-92. 
6. Aliev A.M., Shabanova Z.A., Kerimov A.I. Synthesis and study of zeolites modified with metal cations as catalysts in the oxidative dehydration reaction of naphthenic hydrocarbons. Russian Journal Of Applied Chemistry. 2017, vol. 90, no. 5, p. 591-597. http://j-applchem.ru
7. Aliyev A.M., Shabanova Z.A., NajafGuliyev U.M. Selection of active modified zeolite catalyst and kinetics of the reaction of selective oxidative dehydrogenation of cyclohexane to cyclohexadiene 1,3. Modern Researches in Catalysis. 2015, vol. 4, pp. 8796.

\title{
MODIFIKASIYYA OLUNMUS SEOLITLOR ÜZORINDO METILTSIKLOHEKSANIN OKSIDLOSDIRICI DEHIDROGENLOSMO REAKSIYASININ KINETIK QANUNAUYĞUNLUQLARININ ÖYRONILMOSI
}

\section{Ә.i. Korimov}

AMEA-nın akad. M.Nă̆gyev adına Kataliz və Qeyri-üzvi Kimya İnstitutu AZ 1143, Bakı, H.Cavid pr., 113; e-mail: kerimov.alibala@mail.ru

Metilsikloheksanın CoCr-klinoptilolit katalizatoru üzorindo oksidloşdirici dehidrogenlaşmə reaksiyasının kinetic qanunauyğunluqları araşdırılmışdır. Daxili və xarici diffuziya tormozlanmanın olmaması tasbit edildi, yəni reaksiya kinetic bölgado davam edir, burada bütün diffuziya mərhəlalori bu reaksiyanın mexanizmini taşkil edən bütün kimyəvi mərhəlalarə nisbətən daha sürotli gedir. Reagentlorin parsial tozyiqlarinin, reaksiya temperaturu vo reaksiya qarışığının hacmi süratinin reaksiya gedişinə təsiri öyranilmişdir. Maqsadli reaksiya məhsulunu almaq üçün optimal şartlar müayyan edilmişdir.

Açar sözlar: metiltsikloheksan ,metiltsikloheksadien, oksidlaşdirici dehidrogenlaşmə, klinoptilolit, naften karbohidrogenlari.

\section{ИССЛЕДОВАНИЕ КИНЕТИЧЕСКИХ ЗАКОНОМЕРНОСТЕЙ ПРОТЕКАНИЯ РЕАКЦИИ ОКИСЛИТЕЛЬНОГО ДЕГИДРИРОВАНИЯ МЕТИЛЦИКЛОГЕКСАНА НА МОДИФИЦИРОВАННЫХ ЦЕОЛИТАХ}

\author{
А.И. Керимов \\ Институт катализа и неорганической химии им. акад. М.Нагиева \\ Начиональной АН Азербайджана \\ AZ 1143 Баку, пр.Г.Джавида, 113; e-mail: kerimov.alibala@mail.ru
}

\begin{abstract}
Исследовань кинетические закономерности протекания реакиии окислительного дегидрирования метилииклогексана на катализаторе СоСr-клиноптилолит. Установлено отсутствие внутренне- $и$ внешне-диффузионного торможения, т.е. реакция протекает в кинетической области, в которой все диффузионные этапь протекают значительно быстрее всех химических стадий, составляющих механизм этой реакции. Изучено влияние парииальных давлений реагентов, температуры реакции и объёмной скорости реакционной смеси на протекание реакиии. Определень оптимальные условия получения целевого продукта реакиии.
\end{abstract}

Ключевые слова: метилциклогексан, метилциклогексадиен, окислительное дегидрирование, клиноптилолит, нафтеновые углеводородыл. 